\title{
Induced Breeding of Freshwater Fishes and Cost Benefit Analysis of a Selected Fish Hatchery in Jashore, Bangladesh
}

\author{
Anusree Biswas ${ }^{a}$, Moumita Choudhury ${ }^{b}$, Md. Almamun Farid ${ }^{a}$ \\ M. Aminur Rahman ${ }^{a^{*}}$ and M. Anisur Rahman ${ }^{a^{*}}$ \\ ${ }^{a}$ Department of Fisheries and Marine Bioscience, Faculty of Biological Science and Technology, \\ Jashore University of Science and Technology, Jashore-7408, Bangladesh. \\ ${ }^{b}$ Department of Environmental Science and Technology, Faculty of Applied Science and Technology, \\ Jashore University of Science and Technology, Jashore-7408, Bangladesh.
}

Authors' contributions

This work was carried out in collaboration among all authors. All authors read and approved the final manuscript.

Article Information

DOI: $10.9734 / A R R B / 2021 / \mathrm{v} 36 i 1130446$ Editor(s):

(1) Dr Paola Angelini, University of Perugia, Italy.

Reviewers:

(1) A. Agus Tjahjono, Indonesia

(2) Amira Aicha Beya, Badji Mokhtar University, Algeria. Complete Peer review History, details of the Editor(s), Reviewers and additional Reviewers are available in this link: https://www.sdiarticle5.com/review-history/76963

Original Research Article

Received 09 September 2021

Accepted 19 November 2021

Published 24 November 2021

\section{ABSTRACT}

An investigation was carried out to know the induced breeding techniques of some firewater fish species such as rui (Labeo rohita), catla (Catla catla), silver carp (Hypophthalmichthys molitrix), grass carp (Ctenopharyngodon idella), common carp (Cyprinus carpio), bighead carp (Hypophthalmichthys nobilis), sharpunti (Puntius sarana) and bata (Labeo bata) at Ma Fatima Fish Hatchery in Chanchra, Jashore, Bangladesh. The cost-benefit analysis was also performed on this hatchery for three months from May to July, 2016. The brood fishes purchased from different local sources were used for spawning. The hatchery mainly practiced induced breeding by maintaining proper age and weight of brood stock during spawning. The ranges of fertilization and hatching rates of the experimental fishes were $80.04 \pm 1.44 \%$ to $94.35 \pm 0.54 \%$ and $75.34 \pm 3.49 \%$ to $88.68 \pm 2.76 \%$, respectively. Total spawn production was 960,862 and $734 \mathrm{~kg}$, and the total revenue income from spawn sell was BDT 2,883,500, 2,355,100 and 1,844,800 (BDT $85=1$ US\$) in May, June and July, respectively. Estimated capital cost was BDT 87,90,000, while the operating 
costs were BDT 1,810,650; 1,555,105 and 1,267,680 in May, June and July, respectively. The calculated cost-benefit ratios in May, June and July were 1.59, 1.51 and 1.46, respectively. The hatchery got the highest net profit of BDT (Bangladeshi Taka) 1,041,906 in May due to the highest production and higher price of spawn, and the lowest profit of BDT 546,176 was obtained in July. So, May was found to be the peak breeding month of Ma Fatima Hatchery. The estimated costbenefit ratio indicated that the spawn production through induced breeding techniques was profitable for the hatchery owners.

Keywords: Hatchery; freshwater fishes; pituitary glands; induced breeding; spawn; cost-benefit.

\section{INTRODUCTION}

Bangladesh is blessed with the unbounded and richest fisheries resources in the form of rivers, beels, baors, haors, lakes, ponds, floodplains, estuaries, the Bay of Bengal etc. The fish and fisheries play an exigent role in the national economy of Bangladesh, providing employment, animal protein, earing foreign currency and reducing poverty in the country [1]. Bangladesh is one of the world's leading fish producing country with a total production of 4.384 million MT in 2018-2019 [2]. Fisheries sector alone contributes $1.23 \%$ of the total export earnings, which amounts 4250.31 Core BDT and this sector also contributes $3.50 \%$ to the Gross Domestic Product (GDP) in 2018-2019 [3]. Fish culture is increasing very quickly with the increase in demand. As the people have started aquaculture business in Bangladesh, the demand of fish seed is increasing gradually. Nowadays, fish hatchery is one of the main sources of fry production and about $98 \%$ fry of the country is produced by the hatcheries. It seems likely that the established new hatcheries are playing an active role in the fish production of Bangladesh [4]. There are around 1078 (including 143 government hatcheries) fish hatcheries in Bangladesh. In the year 2019, the total fry production in Bangladesh was 664,020 $\mathrm{kg}$ [3].

Jashore has been considered as one of the richest districts in respect of unique fisheries resources [5]. A large number of public and private hatcheries are present in this district. The availability of fish fry is an essential prerequisite for aquaculture. Hatchery is the main source of spawn production through induced breeding. The first successful induced spawning in Bangladesh was performed by Ali [6] in carps through hypophysation and then standardized accordingly [7-9].

The species of fish included in this study, either individually or as group are normally known as carps and two SIS species. The species referred to as carps including major carps (rui and catla), exotic carps (silver carp, grass carp, common carp and bighead carp) and two SIS (small indigenous species) species (sharpunti and bata).

Carp seed production is a profitable business in Bangladesh. As a result, many investors get ready to invest in aquaculture. However, before the investment, it is important to determine whether the planned investment idea is feasible or not. Carrying out a feasibility analysis is therefore, the most important step in the decision-making process for any investment. Cost-benefit analysis may also assist the manager in making decisions and in adjusting to the changes occurred [10].

Knowledge of production costs and their evolution is essential to the successful management of a hatchery farm. In order to make profit from hatchery, it is a very important task to analyze cost, return and benefit of seed production. Very limited numbers of researches have been conducted focusing the detailed economics of fish hatchery in Bangladesh. Therefore, the aim of this study was to explore the induced breeding techniques used in fish hatchery and to analyze the cost-benefit of the hatchery produced spawn at the representing $\mathrm{Ma}$ Fatima Fish Hatchery in Jashore, Bangladesh.

\section{MATERIALS AND METHODS}

\subsection{Study Area and Duration}

The study was conducted at Ma Fatima Fish Hatchery in Chanchra, Jashore, Bangladesh (Fig. 1) during the month from May to July, 2016. This is a private hatchery, which was rewarded the National Gold Medal by the Government of Bangladesh during the "Jatio Motso Sopthaho Puruskar 2010". In Chanchra region, more than 30 hatcheries are dealing with fish breeding and among them the demand of Ma Fatima Fish Hatchery produced spawn/larvae is high. 


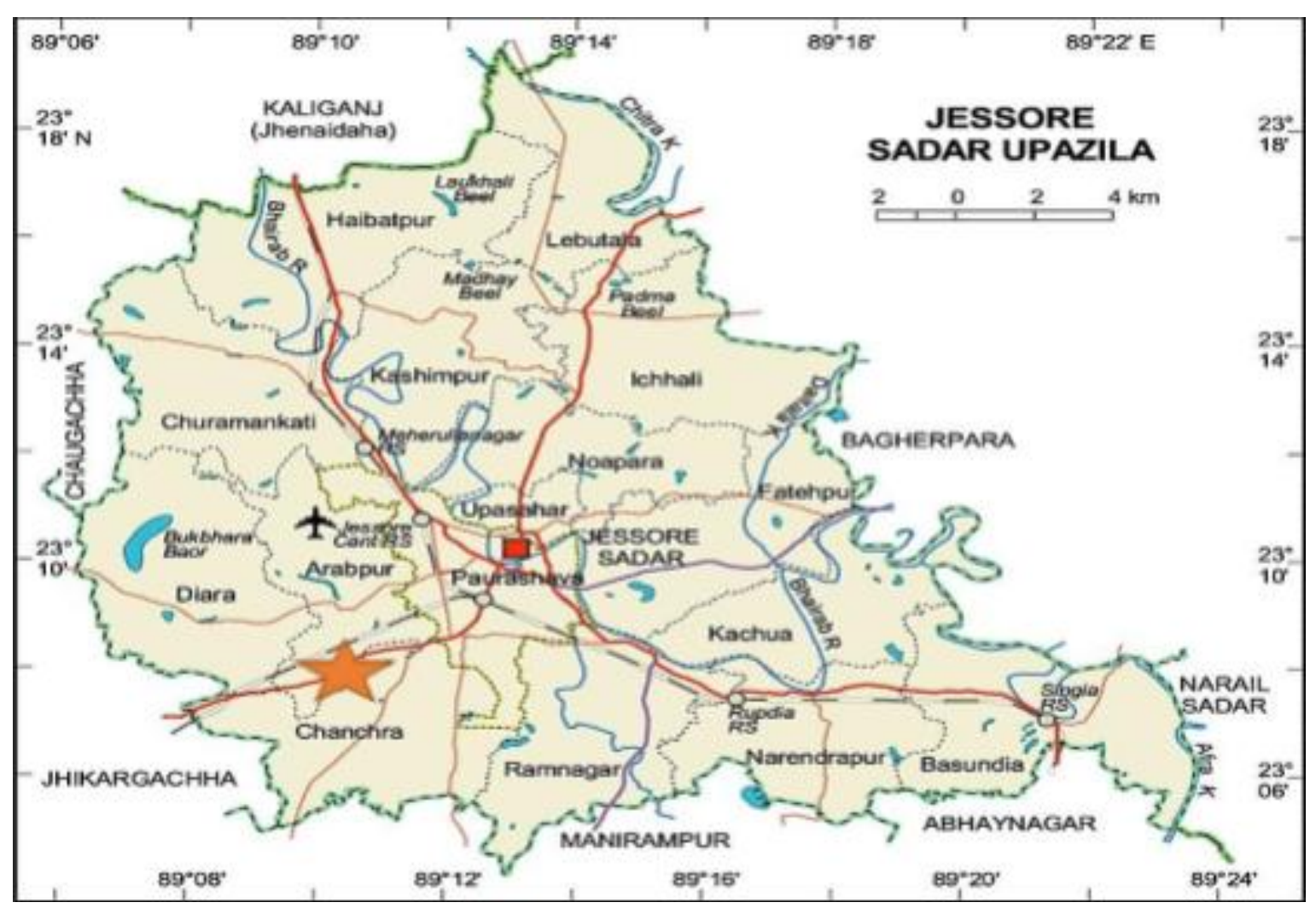

Fig. 1. Map of Jashore Sadar Upazila with the star mark showing the study area of Chanchra, Jashore

\subsection{Collection and Rearing of Brood Fishes}

The healthy and matured brood fishes were collected from the different fish farmers of Jashore district as well as different parts of Bangladesh with the help of District Fisheries Officer (DFO), Jashore and World Fish Centre, Bangladesh. The collected fishes were reared with quality feeds and fertilizers in well-prepared brood ponds under the Ma Fatima Fish Hatchery for about 2 months before the start of the experiment.

\subsection{Collection and Preparation of Pituitary Glands (PG)}

Locally available dry carp PG, manufactured by a Local Enterprise, were collected from the market in an acetone-preserved condition in airtight vials. The pituitary glands were gently removed from the vial with a forceps and dried by using filter papers for 2-3 minutes and then weighed by an analytical electronic balance. The amount of $P G$ required for induced breeding was calculated on the basis of the total body weight of brood fishes using the following formula:
Weight of PG $(\mathrm{mg})=\frac{W t \times P t}{1000}$

Where,

Wt represents the total body weight (g) of brood fishes and

Pt represents the weight $(\mathrm{mg})$ of $P G$ to be injected per $\mathrm{kg}$ body weight of fishes.

\subsection{Determination of Fertilization and Hatching Rates}

The fertilization rate was determined, following the formula used by Chakrabarti et al. [11] as below:

Fertilization $(\%)=\frac{\text { Number of fertilized eggs in sample }}{\text { Number of total eggs in sample }} \times 100$

The hatching rate was calculated using the formula used by Rahman et al. [12] as follows:

Hatching $(\%)=\frac{\text { Number of hatchlings in sample }}{\text { Total Number of fertilized eggs in sample }} \times 100$

\subsection{Cost-benefit Analysis}

For a successful hatchery operation, calculation 
of cost-benefit analysis is a crucial aspect. The capital cost, operating cost, revenue income, cost-benefit ratio and net benefit were analyzed.

\subsubsection{Capital cost}

The capital cost includes the cost of assets, renewal and replacement costs of facilities and equipment.

\subsubsection{Operating cost}

The operating cost includes the cost involved to run the hatchery such as salary of labors, brood fish perching cost etc.

\subsubsection{Depreciation cost, total cost and revenue income}

Depreciation cost, total cost and revenue income were calculated following the formulae used by Islam et al [13] as below:

$$
\begin{aligned}
& \text { Annual depreciation cost }=\frac{\text { Capital cost }}{\text { Project life }} \\
& \text { Monthly depreciation cost }= \\
& \qquad \begin{array}{l}
\text { Annual depreciation cost } \\
12
\end{array}
\end{aligned}
$$

Total cost $=$ Operating cost + Depreciation cost

Revenue income $(B D T)=$ Production $(\mathrm{kg}) \times$ Unit price (BDT)

\subsubsection{Net benefit}

Net benefit was calculated by using the simple formula as follows:

Net benefit $=$ Total revenue income - Total cost.

\subsubsection{Cost-benefit ratio}

The cost benefit ratio was determined according to the formula used by Islam et al. [13] as below:

$$
\text { Cost }- \text { benefit ratio }=\frac{\text { Total benefit }}{\text { Operating cost }}
$$

\subsection{Statistical Analysis}

The data obtained from the present study were analyzed for statistical justification. All data such as $P G$ doses, fertilization and hatching performances, costs and benefits were calculated by Microsoft excel using the descriptive statistics and analysis was carried out by the computerized statistical software SPSS version 16.0. The level for statistical significance was set at $p=0.05$.

\section{RESULTS AND DISCUSSION}

\subsection{PG Doses used for Induced Breeding}

Dose of inducing agents is one of the major components for successful induced breeding program on any fish. In the studied Ma Fatima Fish Hatchery, inducing agent such as PG hormone was used for induced breeding to produce quality fish fry from all experimental fishes. In case of rui, catla, grass carp and common carp, $0.5 \mathrm{mg} / \mathrm{kg}$, and silver carp, bighead carp, $0.75 \mathrm{mg} / \mathrm{kg}$ body weight of $P G$ for first dose in female and 1-2 mg PG/kg body weight in male fishes were injected. Akter et al. [14] and Akter et al. [15] adopted more or less the similar practices for induced breeding in various fishes. For the $1 \mathrm{st}$ and 2 nd dose, $P G$ of $0.25 \mathrm{mg} / \mathrm{kg}$ and 4 to $4.5 \mathrm{mg} / \mathrm{kg}$, respectively was used for sharpunti and bata. Minar et al. [16] documented $1 \mathrm{mg} \mathrm{PG} / \mathrm{kg}$ body weight as the $1 \mathrm{st}$ dose for sharpunti and bata in the hatchery of Barisal district. The details of the PG doses for the male and female broods of different fish species in Ma Fatema Fish Hatchery from May to July 2016, are given in Table 1.

\subsection{Fertilization and Hatching Rates}

The fertilization and hatching rates recorded from the experimental fish species during May-July, 2016 are shown in Figs. 2 and 3, respectively. During the month of May, the highest fertilization and hatching rates were documented in most of the experimental fishes at $\mathrm{Ma}$ Fatima Fish Hatchery. The highest fertilization successes for grass carp, catla and rui were $93.43 \pm 1.53 \%$, $92.87 \pm 0.56 \%$ and $91.64 \pm 2.32 \%$, respectively in May (Fig. 2). Similarly, the highest hatching rates for sharpunti, common carp and grass carp were obtained to be $88.68 \pm 2.76 \%, 87.55 \pm 1.65 \%$ and $86.94 \pm 2.77 \%$, respectively in May (Fig.3). Rahman et al. [12] found the fertilization and hatching successes of $80.76 \%$ and $70.98 \%$ for rui at Rupali Fish Hatchery in Jashore. Mishra et al. [17] also documented the fertilization success of $90 \%$ for catla in the month of May. In the present study, no significant differences $(P>0.05)$ were noticed in the fertilization rates of fishes (except sharpunti and bata) between May and June but significant differences $(P<0.05)$ were recognized between May and July (Fig. 2). During the month of June, the highest fertilization rates of $94.35 \pm 0.54 \%$ and $91.45 \pm 2.43 \%$ were obtained in silver carp and bighead carp, respectively (Fig. 2). However, significant differences $(P<0.05)$ in the respective fertilization rates and hatching rates for all experimental 
fishes were found between June and July (Figs. 2 and 3). El-Hawarry et al. [18] recorded the fertilization rate of $92-86 \%$ and hatching rate of $83-89 \%$ in silver carp.

\subsection{Spawn Production and Revenue Income}

The production, selling rate and revenue income of spawn from the experimental fishes in $\mathrm{Ma}$ Fatima Fish Hatchery during different months are shown in Table 2, 3 and 4, respectively. Total spawn production in May, June and July were 960,862 and $734 \mathrm{~kg}$, and the total revenue obtained from the selling of spawn were BDT $2,883,500,2,355,100$ and 1,844,800, respectively. The study showed that the price of spawn was high in the month of May as this was the peak breeding month of production when demand and price were higher than the next two months. Among the eight fish species, the

Table 1. Pituitary hormone (PG) doses used for artificial breeding of male and females of different fish species in the Ma Fatima Fish Hatchery from May to July, 2016

\begin{tabular}{|c|c|c|c|c|c|}
\hline Name of the species & Sex & $\begin{array}{l}\text { First dose } \\
\text { of PG } \\
(\mathrm{mg} / \mathrm{kg})\end{array}$ & $\begin{array}{l}\text { Interval } \\
\text { (h) }\end{array}$ & $\begin{array}{l}\text { Final dose } \\
\text { of } P G \\
\text { ( } \mathrm{mg} / \mathrm{kg})\end{array}$ & $\begin{array}{l}\text { Hatching time } \\
\text { (h) }\end{array}$ \\
\hline Rui (Labeo rohita) & $\begin{array}{l}\text { Female } \\
\text { Male }\end{array}$ & $\begin{array}{l}0.5 \\
-\end{array}$ & 6 & $\begin{array}{l}6-7 \\
1-2\end{array}$ & $15-20$ \\
\hline Catla (Catla catla) & $\begin{array}{l}\text { Female } \\
\text { Male }\end{array}$ & 0.5 & 6 & $\begin{array}{l}6-7 \\
1-2\end{array}$ & $15-20$ \\
\hline $\begin{array}{l}\text { Silver carp } \\
\text { (Hypophthalmichthys molitrix) }\end{array}$ & $\begin{array}{l}\text { Female } \\
\text { Male }\end{array}$ & 0.75 & 6 & $\begin{array}{l}6-6.5 \\
1.52\end{array}$ & $18-24$ \\
\hline $\begin{array}{l}\text { Grass carp } \\
\text { (Ctenopharyngodon idella) }\end{array}$ & $\begin{array}{l}\text { Female } \\
\text { Male }\end{array}$ & 0.5 & 6 & $\begin{array}{l}5-5.5 \\
1-2\end{array}$ & $18-24$ \\
\hline $\begin{array}{l}\text { Bighead carp } \\
\text { (Hypophthalmichthys nobilis) }\end{array}$ & $\begin{array}{l}\text { Female } \\
\text { Male }\end{array}$ & 0.75 & 6 & $\begin{array}{l}6-7 \\
1.5-2\end{array}$ & $18-24$ \\
\hline $\begin{array}{l}\text { Common carp (Cyprinus } \\
\text { carpio) }\end{array}$ & $\begin{array}{l}\text { Male } \\
\text { Female }\end{array}$ & 0.5 & 6 & $\begin{array}{l}5-5.5 \\
1-2\end{array}$ & $24-36$ \\
\hline Sharpunti (Puntius sarana) & $\begin{array}{l}\text { Female } \\
\text { Male }\end{array}$ & 0.25 & 6 & $\begin{array}{l}4-4.5 \\
0.75-1\end{array}$ & $15-20$ \\
\hline Bata (Labeo bata) & $\begin{array}{l}\text { Female } \\
\text { Male }\end{array}$ & 0.25 & 6 & $\begin{array}{l}4-4.5 \\
1-1.5\end{array}$ & $15-20$ \\
\hline
\end{tabular}

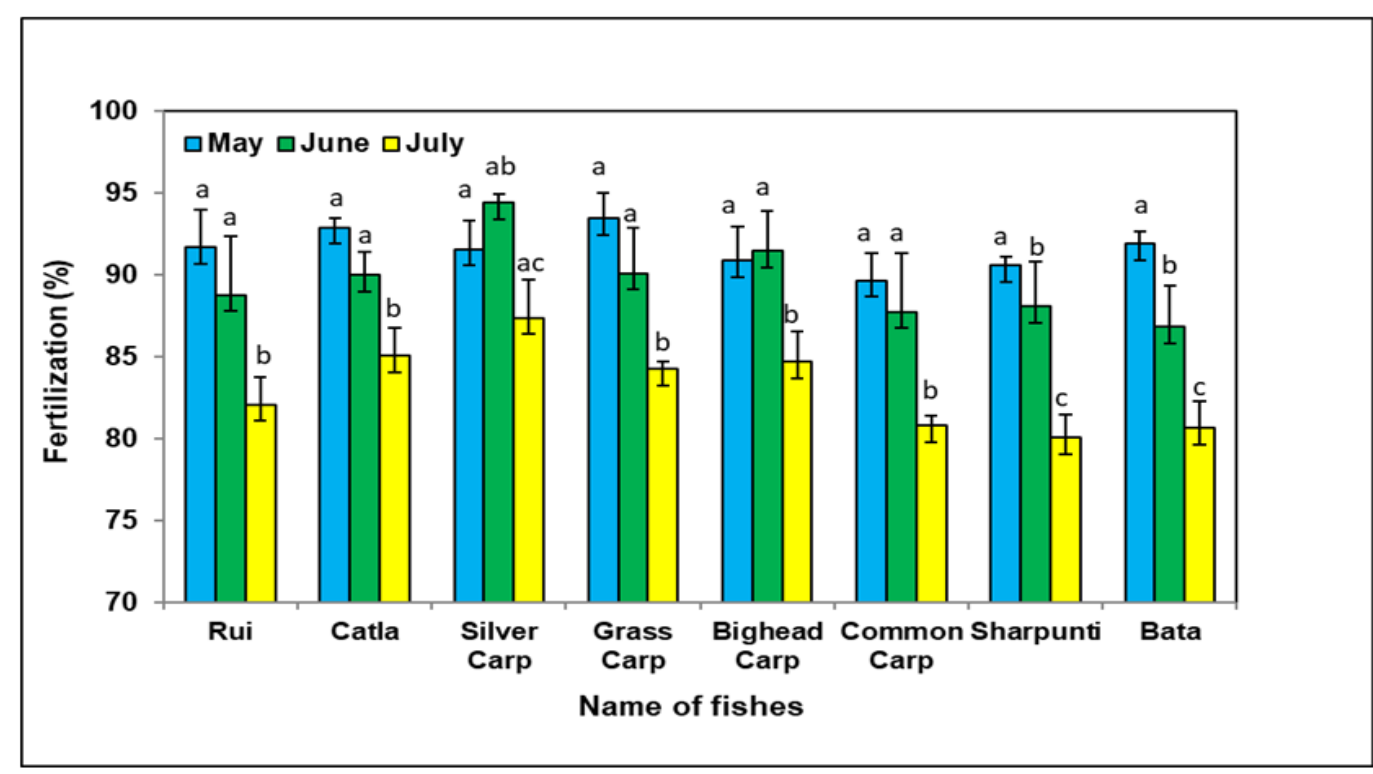

Fig. 2. Mean $\pm S D$ fertilization rates of the experimental fishes from May to July, 2016 in Ma Fatima Fish Hatchery, Jashore. Columns with same letters represent means that are not significantly different $(P>0.05)$ 


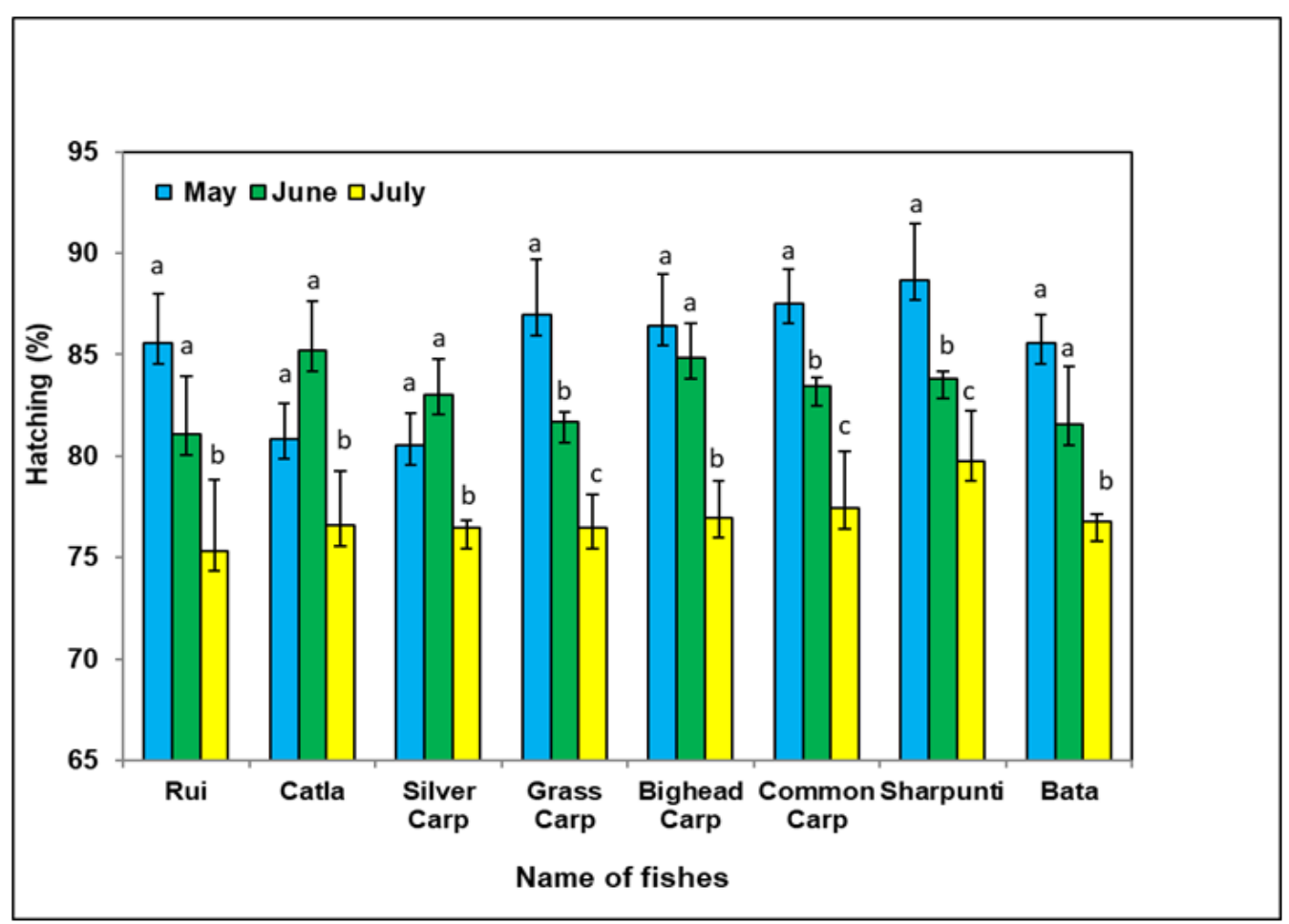

Fig. 3. Mean $\pm S D$ hatching rates of the experimental fishes from May to July, 2016 in Ma Fatima Fish Hatchery, Jashore. Columns with different letters represent means that are significantly different $(P<0.05)$

Table 2. Total spawn production and revenue income from the induced breeding of different fish species in Ma Fish Hatchery during the month of May, 2016

\begin{tabular}{llll}
\hline $\begin{array}{l}\text { Name of } \\
\text { fishes }\end{array}$ & $\begin{array}{l}\text { Production of spawn } \\
(\mathbf{k g})\end{array}$ & $\begin{array}{l}\text { Average rate/kg spawn } \\
\text { (BDT) }\end{array}$ & $\begin{array}{l}\text { Revenue } \\
\text { income(BDT) }\end{array}$ \\
\hline Rui & 360 & 2,500 & 900,000 \\
Catla & 40 & 4,100 & 164,000 \\
Silver carp & 185 & 2,550 & 471,750 \\
Grass carp & 92 & 4,650 & 427,800 \\
Bighead carp & 55 & 3,950 & 217,250 \\
Common carp & 130 & 3,250 & 422,500 \\
Sharpunti & 50 & 2,100 & 105,000 \\
Bata & 48 & 3,650 & 175,200 \\
Total & 960 & & $2,883,500$ \\
\hline & ${ }^{*}($ BDT $85=1$ US $\$)$ &
\end{tabular}

production of rui spawn was high and the rate of spawn was BDT 2500/kg in May. As shown in the Tables 2, 3 and 4, the prices of grass carp spawn were always higher than other species. Sharif et al. [19] recorded the price of rui spawn, which was BDT 2000/kg.

\subsection{Capital and Depreciation Costs}

The detailed capital and depreciation costs incurred are summarized in Table 5 . For the construction of hatchery and brood ponds, lands were leased for 30 years, the value of which was BDT 3,000,000. Another BDT 2,000,000 was spent for the construction of hatchery complex. Total capital cost was BDT 8,790,000 (Table 5). Annual depreciation and monthly depreciation costs were BDT 371,333 and 30,944, respectively (Table 5). Monthly depreciation cost depends on the useful project life and total capital cost of the hatchery. If the useful project life is relatively short, monthly depreciation cost will be high. 
Table 3. Total spawn production and revenue income from the induced breeding of different fish species in Ma Fish Hatchery during the month of June, 2016

\begin{tabular}{llll}
\hline $\begin{array}{l}\text { Name of } \\
\text { fishes }\end{array}$ & $\begin{array}{l}\text { Production of spawn } \\
(\mathbf{k g})\end{array}$ & $\begin{array}{l}\text { Average rate/kg spawn } \\
(\text { BDT) }\end{array}$ & $\begin{array}{l}\text { Revenue income } \\
\text { (BDT) }^{*}\end{array}$ \\
\hline Rui & 324 & 2,300 & 745,200 \\
Catla & 46 & 3,800 & 174,800 \\
Silver carp & 187 & 2,300 & 430,100 \\
Grass carp & 84 & 4,200 & 352,800 \\
Bighead carp & 34 & 3,550 & 120,700 \\
Common carp & 107 & 3,000 & 321,000 \\
Sharpunti & 41 & 1,900 & 77,900 \\
Bata & 39 & 3,400 & 132,600 \\
Total & 862 & & $2,355,100$ \\
\hline
\end{tabular}

Table 4. Total spawn production and revenue income from the induced breeding of different fish species in Ma Fish Hatchery during the month of July, 2016

\begin{tabular}{llll}
\hline $\begin{array}{l}\text { Name of } \\
\text { fishes }\end{array}$ & $\begin{array}{l}\text { Production of } \\
\text { spawn(kg) }\end{array}$ & $\begin{array}{l}\text { Average rate/kg } \\
\text { spawn(BDT) }\end{array}$ & $\begin{array}{l}\text { Revenue } \\
\text { income(BDT) }\end{array}$ \\
\hline Rui & 288 & 2,200 & 633,600 \\
Catla & 32 & 3,500 & 112,000 \\
Silver carp & 148 & 2,000 & 296,000 \\
Grass carp & 68 & 3,800 & 258,400 \\
Bighead carp & 28 & 2,900 & 81,200 \\
Common carp & 104 & 2,900 & 301,600 \\
Sharpunti & 35 & 1,750 & 61,250 \\
Bata & 31 & 3,250 & 100,750 \\
Total & 734 & & $1,844,800$ \\
\hline
\end{tabular}

Table 5. Capital and depreciation costs of Ma Fatima Fish Hatchery

\begin{tabular}{lllll}
\hline Items & $\begin{array}{l}\text { Estimated } \\
\text { capital cost } \\
\text { (BDT) }\end{array}$ & $\begin{array}{l}\text { Useful project } \\
\text { life (year) }\end{array}$ & $\begin{array}{l}\text { Annual } \\
\text { depreciation } \\
\text { cost (BDT) }\end{array}$ & $\begin{array}{l}\text { Monthly } \\
\text { depreciation } \\
\text { cost (BDT)* }\end{array}$ \\
\hline Land lease & $3,000,000$ & 30 & 100,000 & 8,333 \\
Hatchery construction & $2,000,000$ & 30 & 66,667 & 5,556 \\
Pond construction & 700,000 & 30 & 23,333 & 1,944 \\
Pond re-excavation & 200,000 & 5 & 40,000 & 3,333 \\
Hatchery pipeline & 500,000 & 30 & 16,667 & 1,389 \\
Office building & 400,000 & 30 & 13,333 & 1,111 \\
Shallow machine & 240,000 & 30 & 8,000 & 667 \\
Deep tube well & 150,000 & 15 & 10,000 & 833 \\
Electricity line & 50,000 & 10 & 5,000 & 417 \\
Equipment & 250,000 & 10 & 25,000 & 2,083 \\
Submersible pump & 500,000 & 30 & 16,667 & 1,389 \\
Laboratory setup & 600,000 & 15 & 40,000 & 3,333 \\
Miscellaneous & 200,000 & 30 & 6,667 & 556 \\
Total & $\mathbf{8 , 7 9 0 , 0 0 0}$ & & $\mathbf{3 7 1 , 3 3 3}$ & $\mathbf{3 0 , 9 4 4}$ \\
\hline
\end{tabular}


Table 6. Outline of the operating costs for three months in Ma Fatima Fish Hatchery

\begin{tabular}{llll}
\hline Cost items & $\begin{array}{l}\text { Estimated cost (BDT) } \\
\text { in May }\end{array}$ & $\begin{array}{l}\text { Estimated cost (BDT) } \\
\text { in June }\end{array}$ & $\begin{array}{l}\text { Estimated cost (BDT) } \\
\text { in July }\end{array}$ \\
\hline Labor salary & 150,000 & 150,000 & 150,000 \\
Brood fish & $1,089,000$ & 882,090 & 653,400 \\
Feed cost & 163,350 & 147,015 & 130,680 \\
Fertilizer & 23,300 & 21,000 & 18,600 \\
PG gland & 200,000 & 180,000 & 150,000 \\
Electricity & 80,000 & 80,000 & 80,000 \\
Fuel cost & 45,000 & 45,000 & 45,000 \\
Medicine & 20,000 & 15,000 & 10,000 \\
Netting cost & 10,000 & 10,000 & 10,000 \\
Selling cost & 30,000 & 25,000 & 20,000 \\
Total & $1,810,650$ & $1,555,105$ & $1,267,680$ \\
\hline & &
\end{tabular}

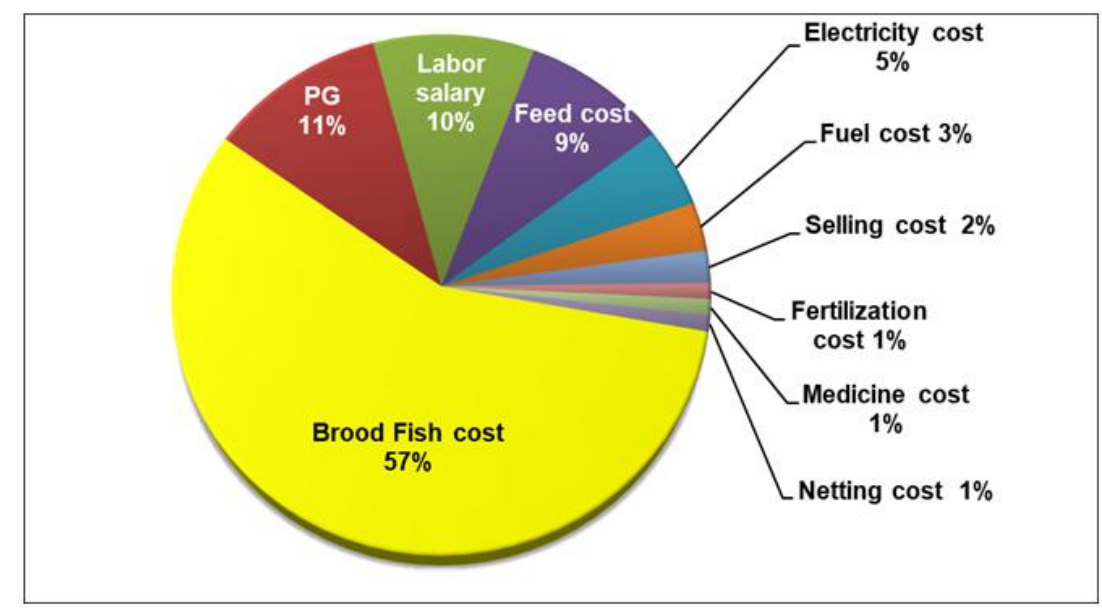

Fig. 4. Percentage of average operating costs for three months in Ma Fatima Fish Hatchery

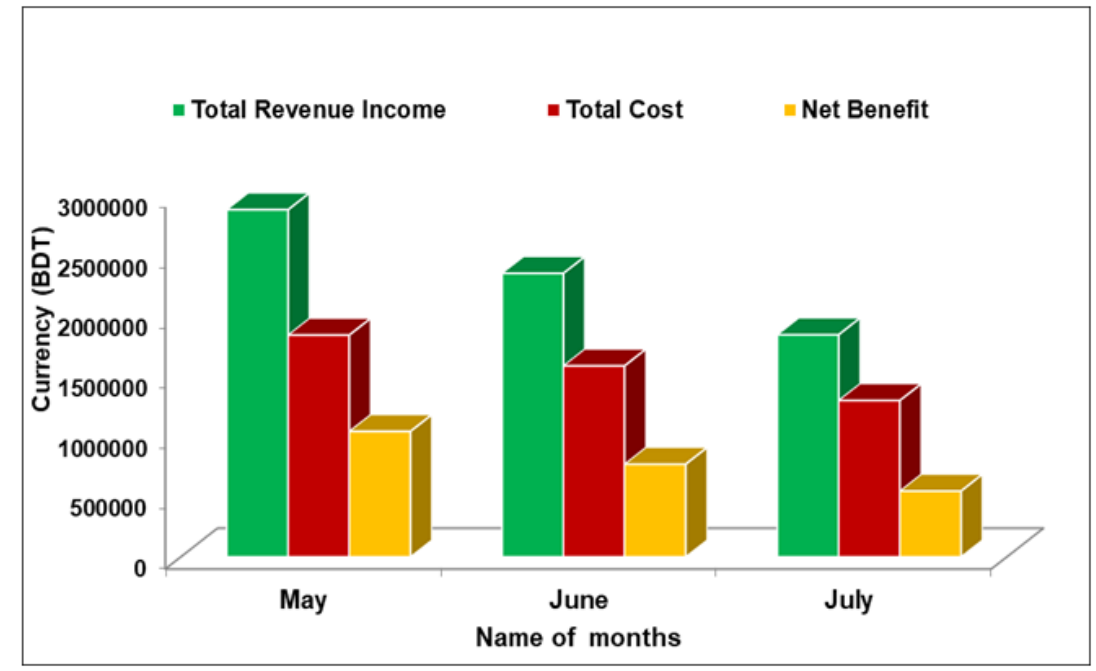

Fig. 5. Monthly revenue income, total cost and net benefit for May, June and July, 2016 in Ma Fatima Fish Hatchery 
Table 7. The estimated cost-benefit ratios for May, June and July, 2016 in Ma Fatima Fish Hatchery in Jashore

\begin{tabular}{lll}
\hline SI. No. & Name of months & Cost-benefit ratio \\
\hline 1 & May & 1.59 \\
2 & June & 1.51 \\
3 & July & 1.46 \\
\hline
\end{tabular}

\subsection{Operating Costs}

Total operating costs and percentage of average operating costs for three months in Ma Fatima Fish Hatchery are shown in Table 6 and Fig. 4, respectively. The hatchery purchased almost $80 \%$ brood fishes from different reliable sources, however, cost of brood fishes were increased or decreased according to the amount and price of them. Feed and fertilizer cost increased as the amount of brood fish increased. PG gland, medicine and selling cost were increased or decreased according to the amount of spawn production. During this study, number of labor and their salary was the same. So, labor cost was same for three months. Highest operating costs recorded in the month of May and that was BDT 1,810,650 (Table 6). Among the total operating costs of the hatchery, highest cost $(57 \%)$ was made due to purchase of brood fish, next highest $(11 \%)$ for inducing agents (PG), followed by salary of labors (10\%) and feeding cost of brood fishes (9\%) (Fig. 4).

\subsection{Total Cost, Revenue Income and Net Benefit}

The total revenue income, total cost and net benefit of May, June and July in Ma Fatima Fish Hatchery are depicted in Fig. 5. Monthly net benefit mainly depends on spawn selling rate and operating costs for the hatchery of the following month. The value of hatchery products such as spawns and fingerlings is also variable depending on several factors, viz. species, supply, demand, season, transportation and quality of spawns. Though the price of brood fish was high in May and low in July, the hatchery got the highest net profit of BDT 1,041,906 in May due to highest production and high price of spawn, and the lowest (BDT 546,176) in July.

\subsection{Cost-Benefit Ratio}

Cost-benefit analysis is very important for any hatchery operation. If monthly total cost and revenue income are known, benefits of any hatchery operation can be understood. During the present study, the cost-benefit ratios of $\mathrm{Ma}$ Fatima Fish Hatchery were estimated and are shown in Table 7. The cost-benefit ratio was in May, June and July were 1.59, 1.51 and 1.46, respectively. Islam et al. [13] documented that the cost-benefit ratios were $1.54,1.32$ and 1.23 in the month of January, February and March.

\section{CONCLUSION}

This study was conducted based on the observations of artificial breeding technique, marketing of hatchery produced spawn of some major carp, exotic carp and SIS species and cost-benefit analysis of Ma Fatima Fish Hatchery in Jashore during the period from May to July 2016. The overall management of brood stock was found to be satisfactory in Ma this Hatchery. The owners were very much careful in hatchery operation so the quality of hatchery produced spawn/larvae was good. They mainly practiced induced breeding by maintaining proper age and weight of brood stock during spawning. Actually aquaculture depends on the availably of quality fish fry and fingerlings. Based on the market demand, the business has been well flourished and lots of people are involved in this business and improved their socio-economic conditions. It had been observed that the price and demand of spawn is very high in May compared other two months. Net benefits was also high in the month of May, so this month represented the peak breeding month. The estimated cost-benefit ratios were $1.59,1.51$ and 1.46 , respectively during the whole experimental period, indicating that the spawn production through induced breeding techniques was profitable for the $\mathrm{Ma}$ Fatima Fish Hatchery.

\section{DISCLAIMER}

The products used for this research are commonly and predominantly used products in our area of research and country. There is absolutely no conflict of interest between the authors and producers of the products because 
we do not intend to use these products as an avenue for any litigation but for the advancement of knowledge. Also, the research was not funded by the producing company rather it was funded by personal efforts of the authors.

\section{ETHICAL APPROVAL}

As per international standard, written ethical permission has been collected and preserved by the author(s).

\section{COMPETING INTERESTS}

Authors have declared that no competing interests exist.

\section{REFERENCES}

1. DoF. National Fish Week Compendium. Department of Fisheries (DoF), Ministry of Fisheries and Livestock, Government of Bangladesh, Dhaka; 2010.

2. DoF. Yearbook of Fisheries Statistics of Bangladesh, 2018-2019. FRSS (Fisheries Resources Survey System), Department of Fisheries (DoF), Bangladesh: Ministry of Fisheries and Livestock, Dhaka, Bangladesh. 2019;36:135.

3. DoF. National Fish Week Compendium. Department of Fisheries (DoF), Ministry of Fisheries and Livestock, Government of Bangladesh, Dhaka; 2020.

4. Amin MR. Fisheries resource development vs. uncontrolled hatchery industry. MPS. 2002;36.

5. Bappa BS, Sabuj Al, Ali M, Jaman HU, Rahamn A. Present status of the fish seed producing hatcheries in the Jashore region, Bangladesh. Int $\mathrm{J}$ Curr Res. 2015;4(3):151-155.

6. Ali MH. Induced breeding of major carps in ponds by pituitary hormone injection. Agric Inform Serv Dhaka. 1967;23-26.

7. Haque KA. Some observations on the induced spawning of major carps by pituitary hormone injection, Freshwater fish. Res. Sta. Chandpur. 1975;1:1933.

8. Islam MZ, Chowdhury AQ. Induced spawning of major carps for commercial production of fry for fish seed in Bangladesh. Bangladesh J Zool. 1976; 4(2):51-61.
9. Ahmed MK. Induced breeding of Indian major carps, Chinese carps and Catfish. Freshwater Fish Research Station Chandpur, Bangladesh. 1983;4452.

10. Hassan S. Benefit-cost analysis for fingerling production of kutum Rutilus frisii kutum in 2005 in Iran. Research and farming techniques. 2008;3539.

11. Chakrabarti PP, Mohapatra CB, Hussan A, Das A, Mandal NR, Ghosh A, Choudhuri G, Jayasankar P. Induced breeding of carps for seed production in FRP hatchery. Adv Appl Sci Res. 2017;8(1):8893.

12. Rahman $\mathrm{MH}$, Rahman MA, Hossain MMM, Haq M, Islam MS, Yeasmin SM. Comparative study on the induced breeding performance of rohu (Labeo rohita) obtained from hatchery and natural sources. Eco-friendly Agril. J. 2013;6(09):205-210.

13. Islam MM, Hassan $R$, Sharif BMN, Rahaman MM, Islam MA, Amin MR. Water quality, feeding management and cost-benefit analysis of a fish hatchery in Jessore district of Bangladesh. Asian J Med Biol Res. 2016;2(3):414-421.

14. Aktar N, Bhuiyan AS, Islam MN. Fry production, induced breeding practices and cost-profit analysis of the hatcheries of Rajshahi district in Bangladesh. J Fish. 2014;2(3):209-214.

15. Akter N, Islam MN. Induced breeding practices of the fish hatcheries in the north-western region of Bangladesh. J Aquac Mar Biol. 2015;2(6):249-252.

16. Minar MH, Shamsuddin M, Bablu MGU, Bhuyan SI. Induced spawning practices of different fisheries in the hatcheries of Barisal district, Bangladesh. Trends Fish Res. 2012;1(2):14-17.

17. Mishra SS, Pradhan P, Dutta CN, Chakaraborty SK. Studies on the performance of Ovatide on breeding of Indian major carps. J Indian Fish Assoc. 2001;28:125-129.

18. El-Hawarry WN, Nemaatallah BR, Shinaway AM. Induced spawning of silver carp, Hypophthalmichthys molitrix using hormones/hormonal analogue with dopamine antagonists. Online J Anim Feed Res. 2012;2(1):58-63. 
19. Sharif BMN, Asif AA. Present status of fish hatchlings and fry production management in greater

Jessore, Bangladesh. International $J$ Fish Aquat Stud. 2015;2:123127.

(c) 2021 Biswas et al.; This is an Open Access article distributed under the terms of the Creative Commons Attribution License (http://creativecommons.org/licenses/by/4.0), which permits unrestricted use, distribution, and reproduction in any medium, provided the original work is properly cited.

\section{Peer-review history:}

The peer review history for this paper can be accessed here: https://www.sdiarticle5.com/review-history/76963 